\title{
The time for physical exercise and food habits on anumber of students from Pascani National College
}

\section{AdrianaALBU1, IonuţONOSE², Raluca MihaelaHODORCĂ ${ }^{3 *}$, Cristina-ElenaMORARU 4}

\begin{abstract}
Nutrition and physical activity are external factors that contributes to the health of young people.Eating too abundant and a short time allocated to physical activity are risk factors for obesity.

Material and Methods: The study was conducted on a group of 79 pupils from the 9th, 10th and 11th grade. To this it was considered the time allotted daily to physical activity (less than $15 \mathrm{~min}, 15$ - 45 minutes, 45 minutes) and were evaluated with a habitsquestionnaire of consumption frequency.Final evaluation will be made separately by class.

Results and Discussion: In most cases young allocate exercise between 15-45 minutes/day (58.22\%).Calculated differences are not statistically significant $\left(p>0.05, f=4, \chi^{2}=7.390\right)$ and highlights the lack of concern for the physical activity of the students. Dominant contribution of milk and cheese is just 2-3 times /week and is totally insufficient and potatoes all 2-3 times/week.Instead sweets are consumed 4-7 times/week (64.55\%), by two thirds of the young people surveyed. Conclusions: they eat more sweets and do insufficient sport so there are favorable conditions for obesity in the adolescents from the study group.
\end{abstract}

Key words: habits, nutrition, physical activity

\section{Rezumat}

Alimentaţia şi activitatea fizică sunt factori externi ce contribuie la menţinerea stării de sănătate a tinerilor. 0 alimentaţie prea abundentă şi un timp scurt alocat activităţii fizice sunt factori de risc pentru apariţia obezităţii.

Material și metode: studiul s-a realizat pe un lot de 79 elevi din clasele a IX a, a X a şi a XI a. La aceştia a fost apreciat timpul alocat zilnic activităţii fizice (sub 15 min, 15-45 minute, peste 45 minute) şi au fost evaluate obiceiurile alimentare cu ajutorul unui chestionar de frecvență a consumului. Aprecierea rezultatelor va fi făcută separat pe clase.

Rezultate şi discuţii: în majoritate cazurilor tinerii alocă exerciţiului fizic între 15 şi 45 minute (58,22\%). Diferenţele calculate sunt nesemnificative statistic ( $\left.p>0.05, f=4, \chi^{2}=7.390\right)$ şi evidenţiază lipsa de preocupare a elevilor pentru activitatea fizică. Aportul dominant de lapte şi brânzeturi este doar de 2-3 ori pe săptămână fiind total insuficient, iar de cartofi tot de 2-3 ori. În schimb dulciurile sunt consumate de 4-7 ori (64,55\%) pe săptămână de două treimi din tinerii chestionaţi.

Concluzii: se mănâncâ multe dulciuri şi de face puţin sport, existând condiţii favorabile pentru apariţia obezităţii la adolescenţi din lotul de studiu.

Cuvinte cheie: obiceiuri, alimentaţie, activitate fizică

\footnotetext{
${ }^{1}$ Assoc.Prof., "Grigore T. Popa" University of Medicine and Pharmacy, Iaşi, Romania

${ }^{2}$ Assoc.Prof., "AlexandruloanCuza" University of Iasi, Romania, Faculty of Physical Education and Sport

${ }^{3}$ Assist.Prof., "AlexandruIoanCuza" University of Iasi, Romania, Faculty of Physical Education and Sport, e-mail: raluca.hodorca@yahoo.com

${ }^{4}$ Assist.Prof., "AlexandruIoanCuza" University of Iasi, Romania, Faculty of Physical Education and Sport
} 


\section{Introduction}

Adolescence marks the transition from childhood to adulthood. This phase is characterized by major changes in the physical and mental. Particular attention is paid to adolescent physical appearance and identification with current ideal of beauty. This identification raises many problems because the current ideal of beauty is skinny and boys with well-developed muscle mass [1]. Healthy teen is shapely, but can not compare with this ideal, so it can manifest dissatisfaction with their bodies.Young people are trying to solve the problem by resorting to various diets and various miraculous cures obtained from the Internet. Obviously the result is below expectations, so it is necessary to change the course of diets and remedies obtained on the Internet [2]. It can get to a situation where the health of adolescents is affected.

Educational programs conducted in schools in this regard must be coherent and have to guide students towards a healthy lifestyle. Healthy lifestyle involving the systematic physical exercise and ensuring a balanced diet [3]. Unfortunately, the systematic production of sustained physical activity is not the main option for young people and neither providing a balanced diet [4]. Returns teachers and school doctors the mission to educate and guide young people in the right direction. However, mass media pressure is very high, and ads are often high in fat and carbohydrate products. Also the national educational programs geared towards chaotic products already consumed in our population, such as fruit.

\section{Study objectives}

Evaluation time for the students surveyed of daily exercise; assessing the dietary habits of the students in the study group; knowing how to change eating habits from one class to another; assessing the changes occurring during exercise provided from one class to another.

\section{Material and methods}

The study was conducted on a group of 79 students from the Pascani National College.It involved students from 9th, 10th and 11th grade, aged between 14 and 18 years old.They were examined 28 students from 9th grade, 26 young people from 10 th grade and 25 from the 11 th. In these young people we applied a questionnaire about the allotted time to exercise and nutrition. The time spent daily on physical exercise was evaluated based on the following choice: maximum 15 minutes, between 15 and $45 \mathrm{~min}$ and over 45 minutes of exercises/day. Eating habits were assessed using a weekly frequency of food consumption questionnaire. We insist on weekly intake of milk, cheese, chicken, potatoes and sweets. Said variants are: "How many times per week do you eat ..." - zero; 1 time, 2-3 or 4-7 times/week. Processing of the results will be made using the Pearson Test.

\section{Results}

We insist on two key aspects for maintaining the health of young people, namely the time for daily exercise and nutrition. Students in the study group allocated daily physical activity, especially between 15 and 45 minutes (58.22\%). Drag attention $26.58 \%$ young people who choose under 15 minutes which is very little (Figure 1).

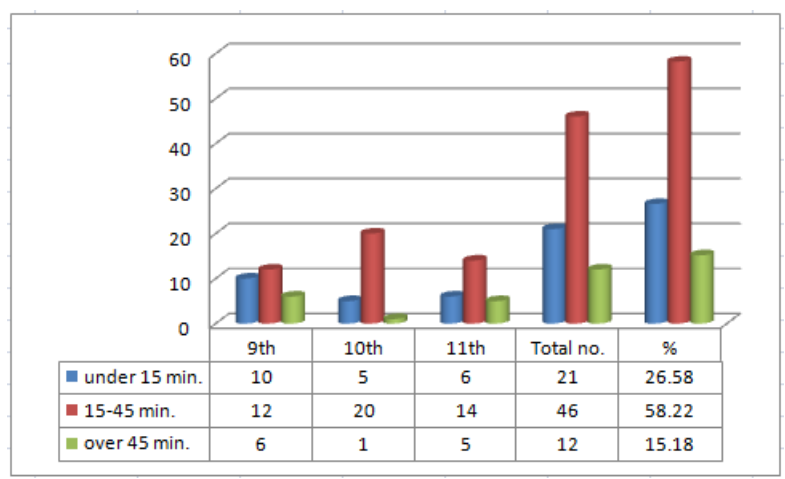

Figure 1. - Time spent by students doing sports

There are young people who understand the role of exercise in maintaining health, so given over 45 minutes of physical activity daily. Calculated differences on grades are not statistically significant ( $p>0.05, f=4, \chi^{2}=7.390$ ) and moving towards a similar concern on students from different grades to practice exercises. Unbalanced diet can contribute to affected health and obesity or malnutrition. We will evaluate weekly consumption of animal 
products (milk, cheese and chicken) and vegetable (potatoes, sweets). Milk is a food rich in protein, fat, vitamins and minerals, but the calorific value is modest [5]. Dominant contribution is 2-3 times a week $(34.17 \%)$ which is totally insufficient. Balanced consumption of milk is recognized only by $22.78 \%$ young, a result which is worrying. At the opposite pole is placed $16.45 \%$ young people who choose zero, which don't consume this product (Figure 2).

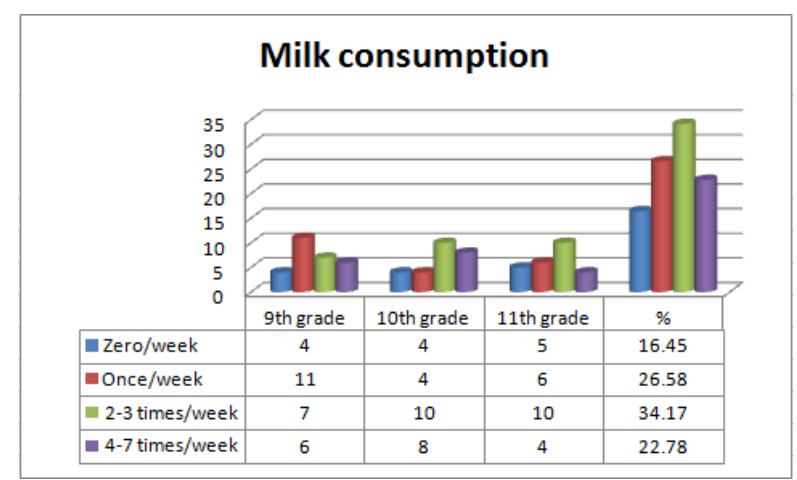

Figure 2. The frequency of weekly milk consumption on the questioned students

Calculated differences are not statistically significant on classes $\left(p>0.05, f=6, \chi^{2}=5.700\right)$ and directs the existence of food errors similar in the students surveyed. Poor milk intake can be compensated by the presence of the cheese in the menus. They contain milk components in quantities much higher.Unfortunately, the result is not encouraging because the dominant contribution is 2 -3 times $(31.64 \%)$ or 1 time $(29.11 \%)$ per week (Figure 3).

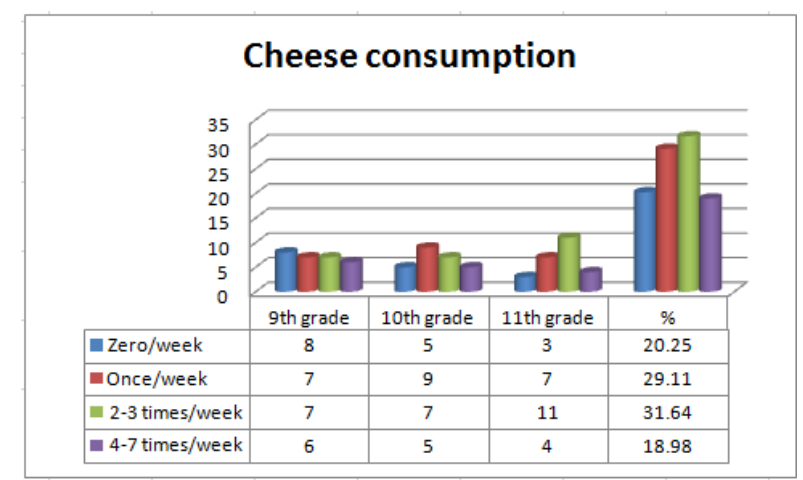

Figure 3. The frequency of weekly cheese consumption on the questioned students
Answers show that 4-7 times intake / week appear in $18.98 \%$, which is balanced but zero contribution (20.25\%) raises many questions. The differences were statistically insignificant $\left(p>0.05, f=6, \chi^{2}=\right.$ 5.385 ) directs the results obtained on the existence of a similar family diet in the students from the study group.

Chicken is recommended in diets by being easy to digest. Obviously this type of meat must be present in te menus of the youth concerned with their body appearance. Dominant consumption is 2-3 times (44.30\%) per week which is totally insufficient.

There are students who marked the zero option (7.59\%) or 1 time per week (18.98\%). Basically, in $25 \%$ of the students, chicken is missing from menus or is consumed in very small quantities. Consumption 4-7 times a week can be considered balanced, only in $29.11 \%$ of students (Figure 4).

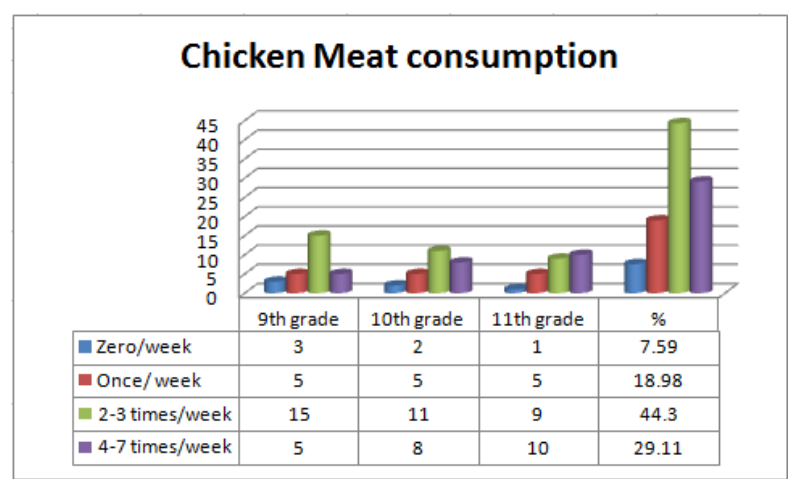

Figure 4. The frequency of weekly chicken meat consumption on the questioned students

Calculated differences are not statistically significant ( $\left.p>0.05, f=6, \chi^{2}=4.279\right)$ and allow for to highlight similar feeding habits and similar nutritional errors. The potato is a vegetable obvious, but in large quantities consumed in our country is passed separately, is considered a special category. We must pay attention to the presence of this product in the menus because it is low in protein and fat, providing a modest caloric intake (6). 2-3 consumption-week is dominant (46.83\%) which is an acceptable result. Drag attention $31.64 \%$ of the students that eat potatoes 4-7 times- 
week.. Possible permanent intake due to easy supply or due to orientation for diets (5).

Orientation is inappropriate because the risk event exposes protein and lipid imbalances and even malnutrition proteolytic calories. Diets do not belong in the periods in which the body develop, as is that of adolescence.

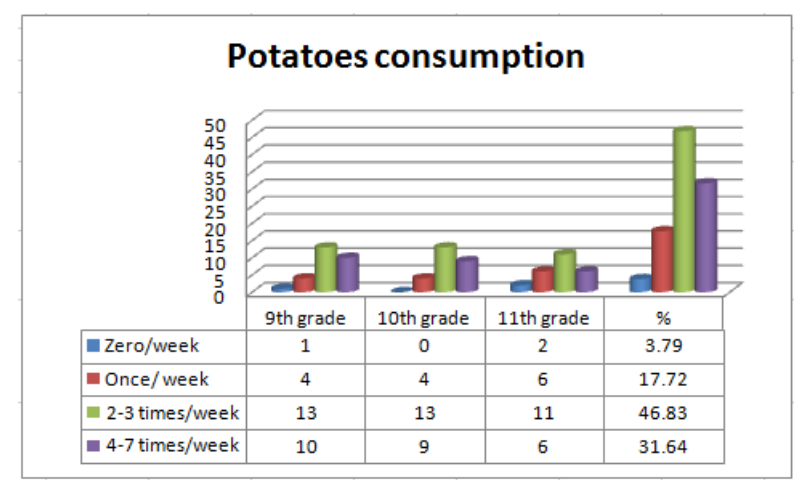

Figure 5. The frequency of weekly potatoes consumption on the questioned students

Calculated differences are not statistically significant ( $\left.p>0.05, f=6, \chi^{2}=5.462\right)$ and emphasize the existence of nutritional errors similar to the students surveyed.

\section{Discussions}

The time alloted to ph Exercises for students interviewed during physical is modest. Similar results were obtained in another study of high school students in Iasi and where physical exerciţil practiced daily over 45 minutes was recognized by $20.0 \%$ youth [7]. It requires consistent implementation of educational programs in which young people are oriented towards systematic practice of physical activity. Study group does not appear to increase interest in practicing physical exercise as you age. I opted for the examination XII graders who are concerned about graduation exams. We opted for pupils of the 9th, 10th and 11 th who do not show increased interest in sport. It may say that the 9 th grade are less time in school (come to school and from schools in the city), but the class 10th and 11th grade they are 1 year or two in school, but the educational programs have not reached the target.
Practiced daily, physical activity associated with balanced nutrition are the basic elements of the maintenance of health and body to ensure a harmonious appearance. Balanced diet involves providing an appropriate dietary intake of food groups. Foods are divided into 11 categories that should be included in the menus. The absence of food categories will be associated with the risk of manifestation of imbalances. The milk is a food product that has a great nutritional value date as the high content of proteins and minerals, especially calcium [8]. Low intake of milk generates manifestation of mineral imbalances, especially spasmophilia appearance. In the study group are present and answers input 1 time per week (26.58\%) or zero $(16.45 \%)$, results that are found in other geographical areas. In a study conducted on a group of teenagers from Bucharest 1 consumer/week responses appear weekly in $10.66 \%$ of cases in women and $8.12 \%$ cases in male. Also, consumption is now very rare or absent in $13.71 \%$ of the surveyed girls and $12.18 \%$ boys [9]. The results are alarming in the study group compared to the adolescents in Bucharest and require nutrition education intervention.

The cheese is slightly consumed even if it has great nutritional value and can choose products less fat and lower calorie [10,11]. Chicken is consumed traditionally in our country and especially in Moldavia. However the result is not encouraging, the dominant values being only 2-3 times a week. Sure you can eatother meat, but pork or beef meat is increasingly less present in the menus feature seen in other studies in Moldavia [12].

Particular attention should be paid to the presence of potatoes in the menus products that is caloric and nutritional modest [13]. Fortunately, the study group does not appear to worry about the result, students do not opt for excessive consumption of potatoes.

The presence of sweets in the diet of adolescents should be closely supervisor, with the possibility of problems when consumed amount is too high or too low. Increased consumption of sweets is associated with excessive intake of "empty calories" calories offered only by carbohydrates [14]. Obviously, in this context there is a risk to obesity evolution and 
even the onset of diabetes. It is not acceptable or insufficient intake, while the nervous system and red blood cells only works on glucose metabolism. Shortage of carbohydrates leads to a malfunction of the nervous system and anemia [15].

Balanced nutrition professionals should emphasize the advantages and disadvantages of a particular food consumption. Students should be informed right through health education classes where information is provided by specialists and not obtained from the Internet or from friends.

\section{Conclusions}

From the study group young people do not engage in physical activity practiced systematically to maintain health and weight control. Eating habits of adolescents in the study group are similar, even if sometimes not the appropriate for the age group. Weight control must be through a balanced diet and sport, not drastic slimming cure.

Diets made by teenagers are a big problem because it can provide sufficient nutrients for growth and development process. It is necessary to initiate educational programs in schools and coherent national programs adapted to the challenges of the school population.

\section{References}

1.Neagu A. (2015).Body image dimensions among Roumanian adolescents, Annuaire Roumain d' anthropologie, Ed. Academiei Române, 52, 41-58.

2.Chevalliere L. (2009).Alimentele, adevăr și impostură, Iași: Ed. Polirom.

3.Alexander R. (2010), Children, their world, their education, London, New York: Ed.Routledge.

4.Milici N. (2016).Comportements alimentaires désordonnés. in vol. "Mondialisation des comportaments alimentaires et facteurs de risques pour l'obésité et le diabète", Simel Press Edt., Sofia, 3649.

5.Fredot É. (2006).Connaisance des aliments,Londres, Paris, New York: Editions Médicales Internationales.

6. Banu C. (2009).Tratat de industrie alimentară, București: Ed.ASAB.

7. Albu A., Onose I., (2016). Relaţia dintre diagnosticul de dezvoltare fizică și timpul acordat activității fizice la un lot de adolescenți din Iași, Antropologie și Sănătate, Ed. Academiei Române.

8.Webster -Gandy J. (2007).Să înțelegem alimentația și nutriţia, București: Ed. Minerva.

9.Milici N., Neagu A. (2014).La consommation de produits laitiers et l'état pondéral chez les adolescents de Bucarest. $\hat{i} n$, ,Mondialisation des comportements alimentaires et facteurs de risques pour l'obesite et le diabete", Simel Press Edt., Sofia, 101115.

10.Fredot É. (2007).Nutrition du bien portant, Londres, Paris, New York: Editions Médicales Internationales.

11.Martin S.A., Tarcea M. (2015), Nutriția sportivului, Târgu Mureș: University Press.

12. Albu A., Hodorcă R.M. (2014).Assessment and food correlation berween body weight in a group of students from sports high school Iassy, Rev. Sport și Societate, vol.14, 15-23.

13.Webster -Gandy J., Maden A. (2006).Oxford handbook of nutrition and dietetics, New York: Oxford University Press.

14.Pop C., Ștef D., Pop M. (2009).Managementul calităţii alimentelor, Iași: Ed. Edict.

15. Zugravu C.A., Cilinca G. (2009).Igiena alimentaţiei și nutriție, București: Ed. Matrix. 